\title{
1: 202767011-202774706
}

National Cancer Institute

\section{Source}

National Cancer Institute. 1: 202767011-202774706. NCI Thesaurus. Code C41732.

Physical location of AVPR1B_Gene 